\title{
Pharmaciana
}

Vol.11, No.3, Nov 2021, Page. 416-426

ISSN: 2088 4559; e-ISSN: 24770256

DOI: $10.12928 /$ pharmaciana.v11i3.18144

\section{Antibacterial compound from Euchema spinosum originated from Tasikmalaya West Java against pathogen bacteria with TLC-bioautography}

\author{
Indra Topik Maulana*, Rifa Safira, Inge Aprianti, \\ Livia Syafnir, Reza Abdul Kodir \\ Pharmacy Program, FMIPA, Universitas Islam Bandung, \\ Jl. Ranggagading No. 8 Bandung 40116, Indonesia
}

\begin{abstract}
Streptococcus mutans (Gram-positive) and Shigella dysenteriae (Gram-negative) are two types of pathogen bacteria. The use of synthetic antibiotics against both bacteria is known to impact the bacteria's resistance. E. spinosum from Tasikmalaya is a potential macroalgae as a source of an antibacterial compound for both bacteria. The research aims to determine the antibacterial metabolite compound from E. spinosum originated from Tasikmalaya against $S$. mutans and $S$. dysenteriae. The research was conducted through several stages, starting from phytochemical screening, gradual maceration using hexane, ethyl acetate, and methanol, determination of antibacterial activity, and TLC-bioautography. Phytochemical screening showed that both raw material and extracts contained alkaloids, flavonoids, and steroids. The result showed that hexane, ethyl acetate, and methanol extract could inhibit the growth of $S$. dysenteriae starting from a concentration of $400 \mu \mathrm{g} / \mathrm{mL}$. However, only ethyl acetate extract can inhibit the growth of $S$. mutans, starting from a concentration of $20 \mu \mathrm{g} / \mathrm{mL}$. The chromatogram of the hexane extract showed the presence of 6 spots, ethyl acetate extract showed 5 , and the methanol extract showed only 4, resulted from the elution system, respectively. The TLCbioautography against $S$. dysenteriae showed that there was the presence of three clear zones on the ethyl acetate extract, detected as flavonoid, and three clear zones on the methanol extract. The TLCbioautography against $S$. mutans showed one clear zone on the chromatogram of ethyl acetate extract. According to the $\mathrm{AlCl}_{3}$ spray reagent confirmation test, the active compound was the flavonoid group.
\end{abstract}

Keywords: Eucheuma spinosum, Streptococcus mutans, Shigella dysenteriae, Tasikmalaya, TLCbioautography

\footnotetext{
*Corresponding author:

Indra Topik Maulana

Prodi Farmasi, FMIPA Universitas Islam Bandung

J1. Ranggagading No. 8 Bandung 40116, Indonesia

Email: indra.topik@gmail.com
} 


\section{INTRODUCTION}

E. spinosum is a species of red algae that grows in Indonesian marine areas. One of which is at Cipatujah Coastal, Tasikmalaya, West Java, Indonesia. Cipatujah is the southern coastal area of the city of Tasikmalaya, directly opposite the Indian Ocean. Unlike the other areas, E. spinosum originated from Cipatujah is still rarely studied due to the absence of cultivation efforts. However, the Indonesian seaweed production from the Euchema $s p$ species was the highest compared to the other seaweed sources in 2015, namely 466,740 dry tons (BPPKP, 2018). Even so, Indonesia was encouraged to become the world's producer of E. spinosum seaweed (KKP, 2018). E. spinosum is widely used as a source of bioactive protein (Hung et al., 2015; Ramadan et al., 2019; Sugrani et al., 2019), carrageenan (Briones and Sato, 2014; Ulumiah et al., 2019), and also as a source of active secondary metabolites (Anestopoulos et al., 2020; Khatulistiani et al., 2019; Othman et al., 2018). Nevertheless, there is still little information related to specific metabolite compounds that have pharmacological properties.

S. dysenteriae and S. mutans are two types of pathogen bacteria that often pose a disease risk for humans, especially in Indonesia. In 2018, Based on Indonesia's health profile data, the incidence of death due to diarrhea was $4.76 \%$. This percentage was the highest level in the last ten years. The report also stated that dental caries was the most common health risk, especially in adolescents (12-17 years). According to the Basic Health Research conducted by the Ministry of Health, data of 2018 reported that $57.6 \%$ of the people experienced problems with their teeth and mouth. The primary treatment related to these two diseases was using synthetic antibiotics.

S. dysenteriae (family: Enterobacteriaceae) are gram-negative bacteria that cause severe diarrhea (dysentery), also known as shigellosis (El-Gendy et al., 2012; Puzari et al., 2017). S. dysenteriae has also been shown to have resistance to several antibiotics, such as the fluoroquinolone class, cephalosporins, azithromycin, chloramphenicol, co-trimoxazole, and ampicillin (El-Gendy et al., 2012; Puzari et al., 2017). S. dysenteriae is also able to produce $\beta$-lactamase (Ahmed and Shimamoto, 2015; Puzari et al., 2017), forming biofilms layer (Batista et al., 2018), and could perform chromosomal mutations (Ahmed and Shimamoto, 2015). Meanwhile, S. mutans (family: Streptococcaceae) are gram-positive bacteria that cause tooth decay. The most common treatment for this condition is using fluoride (Mitsuhata et al., 2013). S. mutans can also produce a biofilm layer that makes it resistant to fluoride and synthetic antibiotics (André et al., 2018).

We have not found any information about the antibacterial activity of E. spinosum against $S$. dysenteriae and $S$. mutans. However, E. Spinosum, based on several research results, is known to have pharmacological activities as an antibacterial against B. cereus bacteria (Rarassari et al., 2016), $S$. Aureus (Safitri et al., 2018; Sugrani et al., 2019), P. gingivalis (Mattulada et al., 2018), and E. Coli (Sugrani et al., 2019). Therefore, based on its known antibacterial activity, E. spinosum has the potential to inhibit the growth of $S$. dysenteriae and $S$. mutans bacteria.

The contact TLC-bioautography is often used in several studies to identify and characterize antibacterial compounds from the natural substance (Al-Saman et al., 2018). This method can selectively determine the antibacterial compounds, even without passing an isolation process (Czernicka et al., 2019). Hence, this research aims to determine the antibacterial activity from $E$. spinosum originated from Cipatujah coastal, Tasikmalaya, West Java, against $S$. dysenteriae and $S$. mutans, and to analyze the active metabolite compounds against both bacteria.

\section{MATERIALS AND METHOD \\ Materials}

The raw material used was Euchema spinosum, obtained from Cipatujah Coastal, Tasikmalaya, West Java. The bacteria used included Shigella dysenteriae ATCC 13313 and Streptococcus mutans ATCC 25175. The media used including nutrient broth (Merck), Salmonella Shigella agar (Himedia), and blood agar media (Merck). 


\section{Methods}

\section{Raw material determination}

The identification of $E$. spinosum took place in the Jatinangor Herbarium with identification sheet number 082/HB/02/2019.

\section{Maceration and phytochemical screening}

The E. spinosum material was dried first, then macerated gradually using hexane, ethyl acetate, and methanol solvents. Each of the mixtures was then filtrated and concentrated with a rotary vacuum evaporator to produce three viscous extracts, namely hexane, ethyl acetate, and methanol extracts. The raw material and the extracts were then analyzed for their chemical content, including:

Alkaloids: 2 grams of raw material and the extracts of $E$. spinosum were placed in different Erlenmeyer. Each of them was acidified with $2 \mathrm{~N} \mathrm{HCl}$ and then filtered. The filtrate was then alkalized with $10 \% \mathrm{NH}_{4} \mathrm{OH}$ and was added with chloroform. The chloroform layer was then separated and tested using Dragendorf reagent and Mayer reagent. The characterization of the alkaloids appeared in two different colors; orange color for Dragendorff reagent and white precipitation for Mayer reagent.

Flavonoids: 2 grams of raw material were added with water and heated. $5 \mathrm{~mL}$ of $2 \mathrm{~N} \mathrm{HCl}$ was added to the mixture, continued by adding a little Magnesium powder, then filtered. After that, amyl alcohol was put into the filtrate and shaken quickly. The presence of flavonoids was seen from the color appearing on the amyl alcohol layer, where it could be red, yellow, or orange in color.

Monoterpenoids and sesquiterpenoids: The raw material and each extract were dissolved in ether and then filtered. The filtrates were evaporated and dried on a drop plate porcelain. Then, $10 \%$ vanillin reagent in sulfuric acid was added to the dried extract. The appearance of colors was the indication of positive results.

Steroids: The raw material and each extract were dissolved in ether and then filtered. The filtrates were then added by Lieberman Burchard's reagent. The appearance of green-blue color was the indication of steroids.

Tannins and saponins were analyzed using the method conducted by Safitri et al. (Safitri et al., 2018).

\section{Antibacterial assay from all extracts}

The stock solution of E. spinosum extract was prepared by dissolving $50 \mathrm{mg}$ extract in $50 \mathrm{~mL}$ of $96 \%$ ethanol. The stock solution was firstly diluted with water to obtain a variant extract concentration of 20, 40, $60 \mu \mathrm{g} / \mathrm{mL}$, and they were called tested extracts. Firstly, S. dysenteriae ATCC 13313 was cultured on SSA media (Alemu et al., 2019), and S. mutans ATCC 25175 was cultured on blood agar (George et al., 2017), both were incubated at $37^{\circ} \mathrm{C}$ for 24 hours.

The assay of extract activity to $S$. dysenteriae applied the disk diffusion method. First, a small portion of the bacteria was dissolved in nutrient broth to produce turbidity equivalent to the standard of 0.5 Mcfarland (Alemu et al., 2019). Second, the suspension was then smeared on the surface of SSA media. Third, the paper disks were dipped in each test solution, including the tested extracts, $96 \%$ ethanol solvent, and $5 \mu \mathrm{g} / \mathrm{mL}$ of cotrimoxazole as the comparator for $S$. dysenteriae assay. Fourth, The disks were then affixed to the SSA surface and incubated at $37^{\circ} \mathrm{C}$ for 48 hours.

The assay of the extract activity to $S$. mutans was conducted with the agar well diffusion method. First, the $S$. mutans culture was smeared on the surface of the media. Second, wells were made on the blood agar medium using a $6 \mathrm{~mm}$ diameter perforator. Third, approximately $50 \mu \mathrm{L}$ of each concentration of the tested extract, $96 \%$ ethanol solvent, and $5 \mu \mathrm{g} / \mathrm{mL}$ of chlorhexidine as the comparator (Jones, 1997) were put into the well using a micropipette. Fourth, the medium containing a tested sample was incubated at $37^{\circ} \mathrm{C}$ for 48 hours. Each of those assays was done under a laminar airflow environment. 


\section{Thin-layer chromatography}

Approximately $30 \mu \mathrm{L}$ of each of $E$. spinosum extracts diluted with each solvent $(1 \mu \mathrm{g} / \mathrm{mL})$ were then spotted onto the activated GF254 TLC plate using a micropipette. The plates were then eluted with the selected eluent combination as shown in Table 1, with an optimized composition than the previous ones.

Table 1. Composition of eluent used in TLC

\begin{tabular}{ccc}
\hline Extract & The Solvent Mixture & Composition \\
\hline Hexane & Hexane : ethyl acetate & $4: 1$ \\
Ethyl acetate & Chloroform : ethyl acetate & $2: 3$ \\
Methanol & Chloroform : aseton & $1: 2$ \\
\hline
\end{tabular}

\section{TLC-bioautography}

The TLC-bioautography was conducted based on the previous methods (Dewanjee et al., 2015). Each chromatogram was then analyzed using the $254 \mathrm{~nm}$ and $366 \mathrm{~nm}$ UV lamp then the number of spots that appeared was calculated. The chromatogram containing the well-separated compound was then attached to the surface of the SSA medium for $S$. dysenteriae and blood agar medium for $S$. mutans for 30 minutes. After that, the chromatogram plate was withdrawn from the medium. Subsequently, the medium was incubated at $37^{\circ} \mathrm{C}$ for 24 hours. Then, the results obtained were observed, and the clear zone that appeared was compared with the chromatogram. Lastly, each spot producing a clear zone was sprayed using $\mathrm{AlCl}_{3}$ and Dragendorff spray reagent.

\section{RESULT AND DISCUSSION}

The results of raw material identification stated that the material used was Euchema spinosum. The pharmacological activity of $E$. spinosum likely depends on the content of the active chemical compounds, especially the secondary metabolites. E. spinosum, based on Phytochemical screening analysis, was known to contain flavonoid, alkaloid, and steroid components (Table 2).

Table 2. Results of phytochemical screening analysis from raw material, extracts of hexane, ethyl acetate, and methanol

\begin{tabular}{cccccc}
\hline Chemical Group & Raw Material & \multicolumn{4}{c}{ Extract } \\
\cline { 3 - 5 } & & Hexane & $\begin{array}{c}\text { Ethyl } \\
\text { Acetate }\end{array}$ & Methanol \\
\hline Flavonoid & + & + & + & + \\
Polyphenols & - & - & - & - \\
Tannin & - & - & - & - \\
Alkaloid & + & + & + & + \\
Saponin & - & - & - & - \\
Steroid & - & + & + & + \\
Monoterpenoid and Sesquiterpenoid & + & + & + & + \\
\hline
\end{tabular}

Information: (+) detected (-) undetected

It is proven that the continuous maceration method with the three solvents could engage the essential secondary metabolite compounds in the material, shown by the detection of three metabolite components in the three extracts. Moreover, the maceration process was also able to attract monoterpenoids and sesquiterpenoids. They are known as the constituents of essential oils, previously being undetected at the time of phytochemical screening in the raw material. Several components of essential oils are known to eliminate $S$. mutans and $S$. dysenteriae actively since they can destroy biofilms made by $S$. mutans (Khan et al., 2020; Tofiño-Rivera et al., 2016) and by $S$. dysenteriae (Batista et al., 2018; Kang et al., 2020). 
Flavonoids are metabolite compounds that have antibacterial activity, especially against $S$. mutans and $S$. dysenteriae. Extracts from several herbs containing flavonoids are known to actively inhibit the growth of $S$. mutans (Jiang et al., 2020) since they can penetrate the film membrane of $S$. mutans (Veloz et al., 2019). Flavonoids could form complex compounds with the constituent compounds of the bacterial cell wall (extracellular protein). It would inhibit the activity of essential enzymes in bacteria (tyrosyl-RNA synthetase enzymes, $\beta$-ketoacyl acyl carrier protein synthase I and III, topoisomerase IV) and inhibit the adhesion process. They also could damage the biofilm layer of bacteria, depolarize membranes, inhibit the synthesis of DNA, RNA, and membrane protein (Farhadi et al., 2019). Zou et al. in their research succeeded in isolating several flavonoids from Selaginella moellendorffii Hieron, being able to damage the biofilm layer, namely 5-carboxymethyl-4'hydroxyflavone-7-O- $\beta$-D-glucopyranosid, 2-(2-(3.4-dihydroxyphenyl)-7-hydroxy-4-oxo-4H-chromen5-yl) acetic acid, (S)-2-(7-hydroxy-2-(4- hydroxyphenyl)-4-oxochroman-5-yl) acetic acid (Zou et al., 2016).

Apart from flavonoids, alkaloids and steroids are signified to have antibacterial activity, especially against $S$. mutans and $S$. dysenteriae. Xu et al. successfully isolated several alkaloid groups such as Fructigenine A, Fructigenine B, and Brevicompanine G from Pleosporales sp (marine fungi) that actively inhibit the growth of $S$. dysenteriae. Xu also successfully isolated the steroid class, namely Ergosta-4,6,8 (14), 22-tetraen-3-one, and (22E) -Ergosta-5,22-dien-3-one that are also known to actively inhibit the growth of $S$. dysenteriae (Xu et al., 2018). Meanwhile, alkaloids can damage the peptidoglycan constituent components in bacterial cells, causing the cell wall layer to not forming appropriately. In addition, alkaloids also inhibit the activity of the topoisomerase enzyme in bacteria (Singkoh et al., 2019). Some of the alkaloids from Rhodophyta algae are the indole alkaloid group (Pérez et al., 2016).

\section{Antimicrobial activity}

Initially, all hexane, ethyl acetate, and methanol extract concentrations did not show the inhibition growth activity against $S$. dysenteriae. However, after the assay was continued with an increase in the concentration measure, all extracts finally showed the inhibition zone starting from a $400 \mu \mathrm{g} / \mathrm{mL}$ concentration (Figure 1). However, only ethyl acetate extract was particularly active against $S$. mutans bacteria and gave an inhibition starting from $20 \mu \mathrm{g} / \mathrm{mL}$ (Table 3 and Figure 1).

Table 3. Clear zone diameter of each extract concentration against $S$. Mutans and S. dysenteriae Bacteria

\begin{tabular}{|c|c|c|c|c|c|c|}
\hline \multirow[b]{2}{*}{ ppm } & \multicolumn{3}{|c|}{ S. mutans } & \multicolumn{3}{|c|}{ S. dysenteriae } \\
\hline & hexane & $\begin{array}{c}\text { Ethyl } \\
\text { acetate }\end{array}$ & methanol & hexane & $\begin{array}{c}\text { Ethyl } \\
\text { acetate }\end{array}$ & methanol \\
\hline 20 & $-*$ & $7.1+0.14$ & $-*$ & $-*$ & $-*$ & $-*$ \\
\hline 40 & $-*$ & $7.9+0.28$ & $-*$ & $-*$ & $-*$ & $-*$ \\
\hline 60 & $-*$ & $9.15+0.21$ & $-*$ & $-*$ & $-*$ & $-*$ \\
\hline 400 & $-* *$ & $-* *$ & $-* *$ & $7.70+0.07$ & $7.78+0.11$ & $8.8+0.07$ \\
\hline 800 & $-* *$ & $-* *$ & $-* *$ & $7.30+0.64$ & $7.30+0.64$ & $7.8+0.07$ \\
\hline 1600 & $-* *$ & $-* *$ & $-* *$ & $8.88+0.11$ & $7.85+0.14$ & $7.25+0.07$ \\
\hline
\end{tabular}




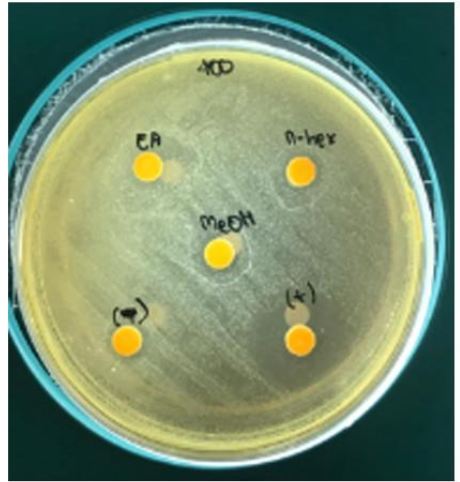

(a)

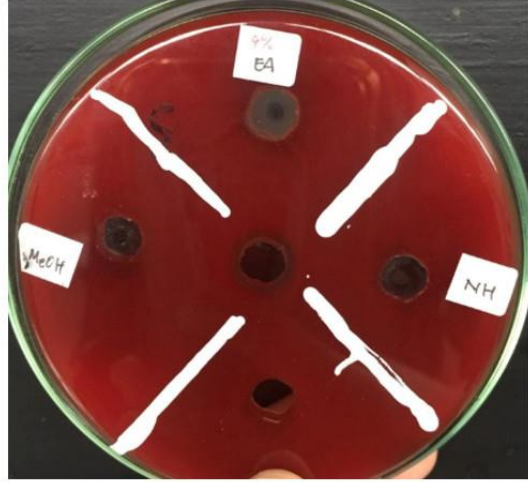

(b)

Figure 1. The inhibition zone from methanolic (MeOH), ethyl acetate (EA), and hexane (NH) extract; (a) concentration of $400 \mu \mathrm{g} / \mathrm{mL}$ of each extract against $S$. dysenteriae on SSA medium with cotrimoxazole as a positive control, (b) $20 \mu \mathrm{g} / \mathrm{mL}$ of each extract against $S$. mutans on blood agar medium with chlorhexidine as a positive control

Although the phytochemical screening showed the same class of compounds present in each extract, the polarity of these compounds was different. Hydrophilicity and lipophilicity are known to affect the antibacterial activity of a compound. Lipophilic extracts from the Rhodophyta division have been proven to inhibit the growth of several bacteria (Cortés et al., 2014). Lipophilic compounds such as flavonoids and terpenoids are known to be able to interact with bacterial cell walls so that they can damage membranes (Dharmautama et al., 2019; Medina-Flores et al., 2016). Lipophilic flavonoids also actively inhibit the growth of both gram-positive and gram-negative bacteria (Farhadi et al., 2019). As an example, Apigenin (4',5,7-Trihydroxyflavone) could reduce the virulence level of $S$. mutans (André et al., 2018). Hydrophilic compounds are also known to actively resist several microbes including the glycoside group, such as aminoglycosides (Nweze et al., 2020), flavonoid glycosides (Zou et al., 2016), and surfactants (Anestopoulos et al., 2020). Hence, the three extracts were continued to the examination using the TLC-bioautography analysis against $S$. dysenteriae bacteria. Meanwhile, the ethyl acetate extract was the only one subjected to the TLCbioautography assay against $S$. mutans.

\section{TLC-bioautography}

TLC analysis of the three extracts resulted in that hexane extract eluted with hexane: ethyl acetate (4:1) showed at least 6 spots. Methanol extract eluted with chloroform: acetone eluent (1:2) showed the presence of 4 spots, and ethyl acetate extract eluted with chloroform: ethyl acetate eluent (2:3) showed 6 spots (Figure 2). Unfortunately, the elution systems could not reproduce the Rf spot with precision, where the elution at different times produces the same number of spots, but with diverse Rf. Each extract was known to contain many compounds with different polarities. It shows that $E$. spinosum is rich in compounds that might likely produce pharmacological activity, especially antibacterial. 


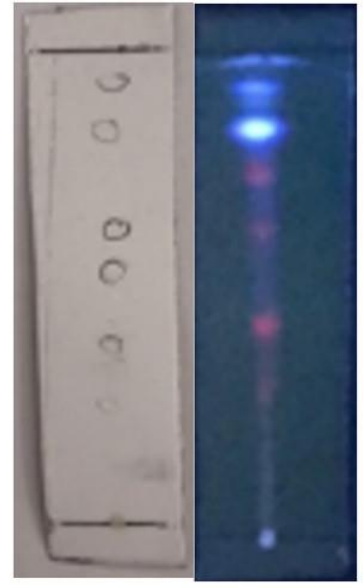

(a)

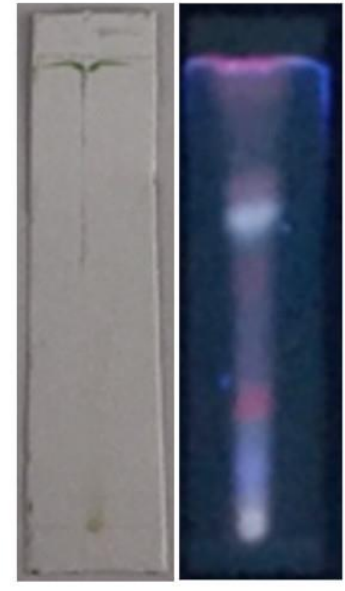

(b)

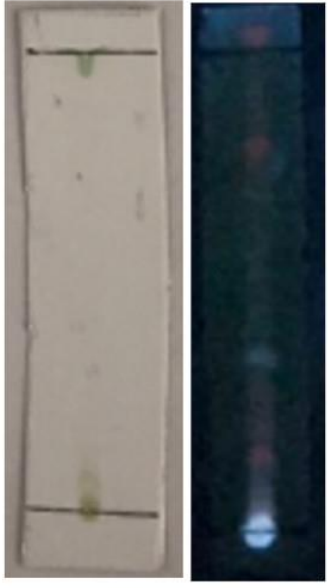

(c)

Figure 2. Chromatogram under visible conditions and under UV lamp 366 nm: (a) hexane extract, (b) ethyl acetate extract, and (c) methanol extract

Bioautographic TLC assay against $S$. dysenteriae showed a clear zone given by methanol and ethyl acetate extracts (Figure 3), while hexane extract showed no clear zones. However, in the methanol extract, a clear zone appeared on the spot with an $\mathrm{Rf}$ between 0.2 to 0.5 . It means that the compound was relatively more polar than the other compounds.

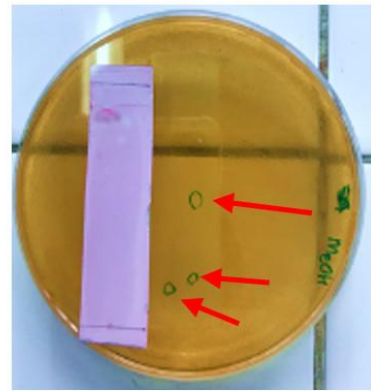

(a)

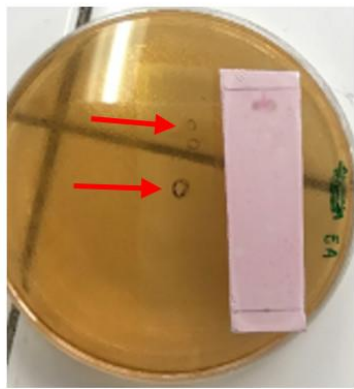

(b)

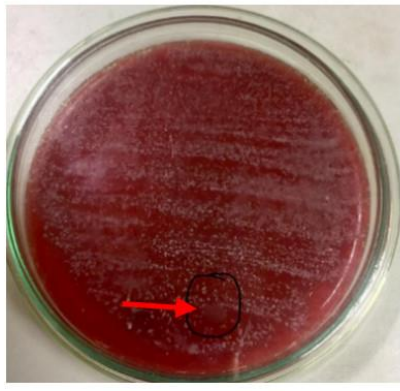

(c)

Figure 3. TLC-bioautography results; (a) methanol extract on SSA medium, (b) ethyl acetate extract on SSA medium (response to $S$. dysenteriae growth), (c) ethyl acetate extract in blood agar medium (response to $S$. mutans growth)

These compounds were probably flavonoids glycosides that can act as a surfactant capable of penetrating bacterial cell wall membranes. The spray reagent assay on the spot showed negative results (Figure 4) where none of the compounds reacted with the spray reagents, but the phytochemical screening confirmed the appearance of flavonoids, proving the possibility of flavone glycosides within. As we know, flavone glycosides with sugar at $\mathrm{C} 5$ would not react with $\mathrm{AlCl}_{3}$ reagents (Harborne, 1973). 


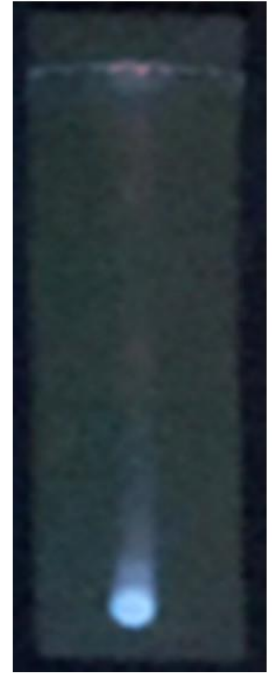

(a)

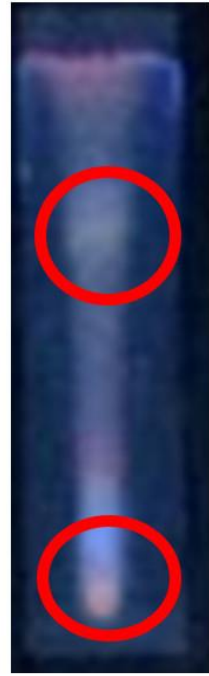

(b)

Figure 4. The results of spraying with $\mathrm{AlCl}_{3}$ spots on (a) methanol extract chromatogram below $366 \mathrm{~nm}$ UV lamp, and (b) ethyl acetate extract chromatogram below $366 \mathrm{~nm}$ UV lamp

As for the ethyl acetate extract, a clear zone appeared on the spot with an Rf between 0.5-0.8. It indicates that the polarity of the compound was semipolar, almost non-polar. The spray reagent assay showed that the spot producing the clear zone reacted with $\mathrm{AlCl}_{3}$ (observed under $366 \mathrm{~nm} \mathrm{UV} \mathrm{lamp}$ lighting). This compound was likely flavonoids of the flavone type, evidenced by its ethyl acetatesoluble nature resulting in a positive outcome in the phytochemical screening and with the $\mathrm{AlCl}_{3}$ reagent (Harborne, 1973). On the other hand, the hexane extract showed no clear zone at all. In this extract, the components of the compound were very non-polar, so it was likely that this compound was unable to penetrate the bacterial cell wall.

The ethyl acetate extract assay against $S$. mutans showed a clear zone at the starting point. It indicates that the compound has a semipolar relative to polar nature. Analysis with $\mathrm{AlCl}_{3}$ showed a positive result in the spot area (Figure 4). The information about the specific active compound needs to be further clarified through the isolation stage to determine which flavonoid groups having an activity to inhibit the growth of both $S$. dysenteriae and $S$. mutans.

\section{CONCLUSION}

It is proven that $E$. spinosum extract can inhibit the growths of $S$. dysenteriae and $S$. mutans bacteria, but only E. spinosum in ethyl acetate extract could inhibit both bacteria. All of the tested extracts might have the ability to inhibit the growth of $S$. dysenteriae starting from $400 \mu \mathrm{g} / \mathrm{mL}$, where only ethyl acetate extract could inhibit $S$. mutans growth starting from $20 \mu \mathrm{g} / \mathrm{mL}$. The class of compounds predicted to have antibacterial activity against the two tested bacteria were flavonoids.

\section{ACKNOWLEDGEMENT}

Thank you to LPPM-UNISBA that has funded this research through a young lecturer research scheme with the number SPK 002/B.04/LPPM/2019 and the author also owes thanks to Prof. I. Sahidin from Halu Oleo University for the important advice to accomplish this manuscript.

\section{CONFLICT OF INTEREST}

The author declared that there is no conflict of interest in this research. The data could be published by the author completely. 


\section{REFERENCES}

Ahmed, A. M., \& Shimamoto, T. (2015). Molecular characterization ofmultidrug-resistant Shigella spp. of food origin. International Journal of Food Microbiology, 194, 78-82. https://doi.org/10.1016/j.ijfoodmicro.2014.11.013

Al-Saman, M., Hamouda, R., Abdella, A., El-Sabbagh, S., \& El-Seoud, G. (2018). TLC Bioautographic Detection and Characterization of Antibacterial Compound from the Cyanobacterium Anabaena oryzae. AJB2T, 3(1), 1-13. https://doi.org/10.9734/ajb2t/2018/39097

Alemu, A., Geta, M., Taye, S., Eshetie, S., \& Engda, T. (2019). Prevalence, associated risk factors and antimicrobial susceptibility patterns of Shigella infections among diarrheic pediatric population attending at Gondar town healthcare institutions, Northwest Ethiopia. Tropical Diseases, Travel Medicine and Vaccines, 5(1), 1-8. https://doi.org/10.1186/s40794-019-0079-7

André, C. B., Chan, D. C., \& Giannini, M. (2018). Antibacterial-containing dental adhesives' effects on oral pathogens and on Streptococcus mutans biofilm: Current perspectives. American Journal of Dentistry, 31(Sp Is B), 37B-41B.

Anestopoulos, I., Kiousi, D. E., Klavaris, A., Maijo, M., Serpico, A., Suarez, A., Sanchez, G., Salek, K., Chasapi, S. A., Zompra, A. A., Galanis, A., Spyroulias, G. A., Gombau, L., Euston, S. R., Pappa, A., \& Panayiotidis, M. I. (2020). Marine- derived surface active agents: Healthpromoting properties and blue biotechnology- based applications. Biomolecules, 10(6), 1-28. https://doi.org/10.3390/biom10060885

Batista, A., Dodou, H., Rodrigues, M., Pereira, P., Sales, G., Medeiros, S., \& Nogueira, N. (2018). Modulatory effect of lippia alba essential oil on the activity of clinically used antimicrobial agents on salmonella typhi and shigella dysenteriae biofilm. Scientia Pharmaceutica, 86(4). https://doi.org/10.3390/scipharm86040052

BPPKP. (2018). Info Komoditi Rumput Laut. In Z. Salim \& Ernawati (Eds.). Al Mawardi Prima.

Briones, A. V., \& Sato, T. (2014). Structural Studies on 1-Carrageenan Derived Oligosaccharides and Its Application. Advances in Chemical Engineering and Science, 04(01), 17-22. https://doi.org/10.4236/aces.2014.41003

Cortés, Y., Hormazábal, E., Leal, H., Urzúa, A., Mutis, A., Parra, L., \& Quiroz, A. (2014). Novel antimicrobial activity of a dichloromethane extract obtained from red seaweed Ceramium rubrum (Hudson) (Rhodophyta: Florideophyceae) against Yersinia ruckeri and Saprolegnia parasitica, agents that cause diseases in salmonids. Electronic Journal of Biotechnology, 17(3), 126-131. https://doi.org/10.1016/j.ejbt.2014.04.005

Czernicka, L., Grzegorczyk, A., Marzec, Z., Antosiewicz, B., Malm, A., \& Kukula-Koch, W. (2019). Antimicrobial Potential of Single Metabolites of Curcuma longa Assessed in the Total Extract by Thin-Layer Chromatography-Based Bioautography and Image Analysis. Int. J. Mol. Sci, 20(4). https://doi.org/10.3390/ijms20040898

Dewanjee, S., Gangopadhyay, M., Bhattacharya, N., Khanra, R., \& Dua, T. K. (2015). Bioautography And Its Scope In The Field Of Natural Product Chemistry. In Journal of Pharmaceutical Analysis (Vol. 5, Issue 2, pp. 75-84). Xi'an Jiaotong University. https://doi.org/10.1016/j.jpha.2014.06.002

Dharmautama, M., Ikhriahni, Manggau, M. A., Tetelepta, R., Malik, A., Muchtr, M., Amiruddin, M., Asse, R. A., \& Arfa, S. (2019). The effectiveness of Sargassum polycystum extract against Streptococcus mutans and Candida albicans as denture cleanser. Journal of International Dental and Medical Research, 12(2), 528-532.

El-Gendy, A. M., Mansour, A., Weiner, M. A., Pimentel, G., Armstrong, A. W., Young, S. Y. N., Klena, J. D., \& Elsayed, N. (2012). Genetic diversity and antibiotic resistance in Shigella dysenteriae and Shigella boydii strains isolated from children aged <5 years in Egypt. Epidemiol. Infect. (2012), 140, 299-310. https://doi.org/10.1017/S0950268811000525

Farhadi, F., Khameneh, B., Iranshahi, M., \& Iranshahy, M. (2019). Antibacterial activity of flavonoids and their structure-activity relationship: An update review. Phytotherapy Research, 33(1), 13- 
40. https://doi.org/10.1002/ptr.6208

George, D. E., Shetty, R., Shetty, P. J., \& Gomes, L. A. (2017). An in vitro study to compare the effect of different types of tea with chlorhexidine on streptococcus mutans. Journal of Clinical and Diagnostic Research, 11(9), ZC05-ZC07. https://doi.org/10.7860/JCDR/2017/26581.10538

Harborne, J. B. (1973). Phytochemical Methods : A guide to modern techniques of plant analysis. In Chapman and Hall in (1st ed.). Chapman \& Hall. https://doi.org/10.1007/978-94-009-5921-7

Hung, L. D., Hirayama, M., Ly, B. M., \& Hori, K. (2015). Purification, primary structure, and biological activity of the high-mannose $\mathrm{N}$-glycan-specific lectin from cultivated Eucheuma denticulatum. Journal of Applied Phycology, 27(4), 1657-1669. https://doi.org/10.1007/s10811$\underline{014-0441-0}$

Jiang, M., Yan, L., Li, K. ao, Ji, Z. hong, \& Tian, S. ge. (2020). Evaluation of total phenol and flavonoid content and antimicrobial and antibiofilm activities of Trollius chinensis Bunge extracts on Streptococcus mutans. Microscopy Research and Technique, February, 1-9. https://doi.org/10.1002/jemt.23540

Jones, C. G. (1997). Chlorhexidine: Is It Still the Gold Standard? Periodontology 2000, 15, 55-62. https://doi.org/10.1111/j.1600-0757.1997.tb00105.x

Kang, J., Liu, L., Liu, Y., \& Wang, X. (2020). Ferulic Acid Inactivates Shigella flexneri through Cell Membrane Destructieon, Biofilm Retardation, and Altered Gene Expression. Journal of Agricultural and Food Chemistry, 68(27), 7121-7131. https://doi.org/10.1021/acs.jafc.0c01901

Khan, M., Alkhathlan, H. Z., \& Khan, S. T. (2020). Antibiotic and antibiofilm activities of Salvadora persica 1. Essential oils against Streptococcus mutans: A detailed comparative study with chlorhexidine digluconate. Pathogens, 9(1). https://doi.org/10.3390/pathogens9010066

Khatulistiani, T. S., Noviendri, D., Munifah, I., \& Melanie, S. (2019). Bioactivities of red seaweed extracts from Banten, Indonesia. IOP Conference Series: Earth and Environmental Science, 404(1). https://doi.org/10.1088/1755-1315/404/1/012065

KKP. (2018). Laporan Tahunan: Profil Peluang Investasi Komoditas Rumput Laut (C. Sarwanto, I. N. Sjarief, H. Susanto, A. Solah, I. Kurnia, C. Aryshandy, D. Kusumah, E. Horida, S. Wahyuni, L. Moriansyah, N. D. Purnama, \& R. Wicaksono (eds.)). Direktorat Usaha dan Investasi.

Mattulada, I. K., Trilaksana, A. C., N, D. A. A. M., Gigi, D. K., Kedokteran, F., \& Universitas, G. (2018). Antibacterial Effectivity of red algae extract (Euchema spinosum) to inhibit the growth of bacteri Porphyromonas gingivalis. Makassar Dent J, 7(1), 40-45

Medina-Flores, D., Ulloa-Urizar, G., Camere-Colarossi, R., Caballero-García, S., Mayta-Tovalino, F., \& del Valle-Mendoza, J. (2016). Antibacterial activity of Bixa orellana L. (achiote) against Streptococcus mutans and Streptococcus sanguinis. Asian Pacific Journal of Tropical Biomedicine, 6(5), 400-403. https://doi.org/10.1016/j.apjtb.2016.03.005

Mitsuhata, C., Puteri, M. M., Ohara, Y., Tatsukawa, N., \& Kozai, K. (2013). Possible involvement of enolase in fluoride resistance in Streptococcus mutans. Pediatric Dental Journal, 1-5. https://doi.org/10.1016/j.pdj.2013.10.002

Nweze, J. A., Mbaoji, F. N., Huang, G., Li, Y., Yang, L., Zhang, Y., Huang, S., Pan, L., \& Yang, D. (2020). Antibiotics development and the potentials of marine-derived compounds to stem the tide of multidrug-resistant pathogenic bacteria, fungi, and protozoa. Marine Drugs, 18(3). https://doi.org/10.3390/md18030145

Othman, R., Amin, N. A., Sani, M. S. A., Fadzillah, N. A., \& Jamaludin, M. A. (2018). Carotenoid and chlorophyll profiles in five species of Malaysian seaweed as potential Halal Active Pharmaceutical Ingredient (API). International Journal on Advanced Science, Engineering and Information Technology, 8(4-2), 1610-1616. https://doi.org/10.18517/ijaseit.8.4-2.7041

Pérez, M. J., Falqué, E., \& Domínguez, H. (2016). Antimicrobial action of compounds from marine seaweed. Marine Drugs, 14(3), 1-38. https://doi.org/10.3390/md14030052

Puzari, M., Sharma, M., \& Chetia, P. (2017). Emergence of antibiotic resistant Shigella species : A matter of concern. Journal of Infection and Public Health. https://doi.org/10.1016/j.jiph.2017.09.025 
Ramadan, R., Ahmad, A., Marinda, Natsir, H., Karim, A., \& Karim, H. (2019). Symbiont bacteria cultures from the red algae Eucheuma spinosum, isolation of bioactive proteins and their anticancer potential test. Journal of Physics: Conference Series, 1341(3). https://doi.org/10.1088/1742-6596/1341/3/032020

Rarassari, M. A., Darius, \& Kartikaningsih, H. (2016). Inhibition Of Eucheuma Spinosum Extract With Different Concentration Of Bacillus Cereus. Samakia: Jurnal Ilmu Perikanan, 7(1), 5-11.

Safitri, A., Srihardyastutie, A., Roosdiana, A., \& Sutrisno, S. (2018). Antibacterial Activity and Phytochemical Analysis of Edible Seaweed Eucheuma spinosum Against Staphyloccocus aureus. The Journal of Pure and Applied Chemistry Research, 7(3), 308-315. https://doi.org/10.21776/ub.jpacr.2018.007.03.389

Singkoh, M. F. O., Mantiri, D. M. H., Lumenta, C., \& Manoppo, H. (2019). Biomineral characterization and antibacterial activity of marine algae tricleocarpa fragilis from kora-kora coastal waters of Minahasa Regency, Indonesia. AACL Bioflux, 12(5), 1814-1822.

Sugrani, A., Natsir, H., Djide, M. N., \& Ahmad, A. (2019). Biofunctional Protein Fraction From Red Algae (Rhodophyta) Eucheuma Spinosum As an Antibacterial and Anticancer Drug Agent. International Research Journal Of Pharmacy, 10(3), 64-69. https://doi.org/10.7897/2230$\underline{8407.100380}$

Tofiño-Rivera, A., Ortega-Cuadros, M., Galvis-Pareja, D., Jiménez-Rios, H., Merini, L. J., \& Martínez-Pabón, M. C. (2016). Effect of Lippia alba and Cymbopogon citratus essential oils on biofilms of Streptococcus mutans and cytotoxicity in CHO cells. Journal of Ethnopharmacology, 194(September), 749-754. https://doi.org/10.1016/j.jep.2016.10.044

Ulumiah, M., Alamsjah, M. A., \& Pursetyo, T. (2019). The Effect of Different pH in Extraction Process Against Physicochemical Properties of Refined Iota Carrageenan from Eucheuma spinosum Seaweed. Journal of Marine and Coastal Science, 8(1), 14-25. https://doi.org/10.20473/jmcs.v8i1.21142

Veloz, J. J., Alvear, M., \& Salazar, L. A. (2019). Antimicrobial and Antibiofilm Activity against Streptococcus mutans of Individual and Mixtures of the Main Polyphenolic Compounds Found in Chilean Propolis. BioMed Research International, 2019. https://doi.org/10.1155/2019/7602343

Xu, Y., Zhu, A., Cao, F., \& Liu, Y. F. (2018). Diketopiperazine Alkaloids and Steroids from a MarineDerived Pleosporales sp. Fungus. Chemistry of Natural Compounds, 54(4), 818-820. https://doi.org/10.1007/s10600-018-2487-8

Zou, Z. X., Xu, P. S., Wu, C. R., Zhu, W. X., Zhu, G. Z., He, X. A., Zhang, G. G., Hu, J. Z., Liu, S., Zeng, W., Xu, K. P., \& Tan, G. S. (2016). Carboxymethyl flavonoids and a chromone with antimicrobial activity from Selaginella moellendorffii Hieron. Fitoterapia, 111, 124-129. https://doi.org/10.1016/j.fitote.2016.04.022 